\title{
Dossiê coronavírus: Quem tem medo da pandemia? Geografias e geopolíticas do Covid-19
}

Guilherme Ribeiro (PPGGEO/UFRRJ), Floriano José Godinho de Oliveira (PPFH/UERJ), Leandro Dias de Oliveira (PPGGEO/UFRRJ) e Regina Tunes (IGEOG/UERJ)

\section{(2) OpenEdition}

1 Journals

\section{Edição electrónica}

URL: http://journals.openedition.org/espacoeconomia/11356

DOI: 10.4000/espacoeconomia.11356

ISSN: 2317-7837

Editora

Núcleo de Pesquisa Espaço \& Economia

Refêrencia eletrónica

Guilherme Ribeiro (PPGGEO/UFRRJ), Floriano José Godinho de Oliveira (PPFH/UERJ), Leandro Dias de Oliveira (PPGGEO/UFRRJ) e Regina Tunes (IGEOG/UERJ), « Dossiê coronavírus: Quem tem medo da pandemia? Geografias e geopolíticas do Covid-19», Espaço e Economia [Online], 17| 2020, posto online no dia 08 abril 2020, consultado o 10 dezembro 2020. URL : http://journals.openedition.org/ espacoeconomia/11356; DOI : https://doi.org/10.4000/espacoeconomia.11356

Este documento foi criado de forma automática no dia 10 dezembro 2020

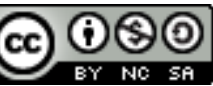

Espaço e Economia - Revista brasileira de geografia econômica est mise à disposition selon les termes de la licence Creative Commons Attribution - Pas d'Utilisation Commerciale - Partage dans les Mêmes Conditions 4.0 International. 


\title{
Dossiê coronavírus: Quem tem medo da pandemia? Geografias e geopolíticas do Covid-19
}

\author{
Guilherme Ribeiro (PPGGEO/UFRRJ), Floriano José Godinho de Oliveira \\ (PPFH/UERJ), Leandro Dias de Oliveira (PPGGEO/UFRRJ) e Regina Tunes \\ (IGEOG/UERJ)
}

1 Por ocasião do surgimento da Espaço e Economia no segundo semestre de 2012, a intenção dos editores fundadores era a de estimular cientificamente o campo da Geografia Econômica no país e, ao mesmo tempo, servir como canal de intervenção político-intelectual sobre temas atuais.

2 Tanto no passado como no presente, o ofício do geógrafo não deve separar ciência e política, pois qualquer tentativa de fazê-lo derivará em uma leitura estéril e ideológica da realidade. Da escolha dos conceitos à publicação dos resultados da pesquisa, a intervenção científica do geógrafo é indissociável da dimensão política organizadora da sociedade. A todos os geógrafos e os cientistas sociais que aceitaram o desafio de escrever em plena ebulição graças à cumplicidade intelectual, afetiva e política que nos une, muitíssimo obrigado.

3 Afinal, se Eric Hobsbawm afirma em "Era dos Extremos" (1994) ${ }^{1}$ que a Segunda Grande Guerra foi uma verdadeira aula de geografia do mundo, a expansão do COVID-19 também se mostra uma aula de geografia do mundo contemporâneo, revelando a todos a face perversa do neoliberalismo, da globalização e da urbanização segregadora.

4 Assim, a difusão do neoliberalismo em escala mundial e suas consequências territoriais em um país periférico como o Brasil representam um projeto de morte para milhões de indígenas, quilombolas e trabalhadores no campo e nas periferias metropolitanas. $\mathrm{Na}$ esteira das "reformas" - o vocábulo é deliberadamente ruim visando mascarar a natureza negativa do processo - trabalhista e previdenciária operadas desde 2016 pelos Governos Temer e Bolsonaro e celebradas com júbilo pelo mercado, o sufocamento da coisa pública em nome da privatização da vida tem sido adotado como norma. 
5 Neste caso, o uso do termo não é acidental. Estamos diante de palavra-chave no entendimento do capitalismo como um sistema obrigado a engendrar diuturnamente a aparência de normalidade, mas que, por sua própria natureza, é incapaz de esconder suas contradições - embora muitas vezes não sejamos capazes de discerni-las.

A pandemia Covid-19 despiu todas elas.

7 Se a solução para o Corona reside em uma vacina, qual será a solução para o vírus da concentração de renda, da superexploração do trabalho, dos juros escandalosos, dos deploráveis lucros bancários bilionários, do Estado autoritário criminalizador de movimentos sociais?

8 A plena resposta não virá nem da Bioquímica, nem da Epidemiologia, mas daquilo que o Estado brasileiro vem fazendo com sua população. Se a normalidade admite a saúde pública à beira da falência, administrar o incremento da necessidade médico-hospitalar será tarefa áspera. Se a normalidade aceita habitações desprovidas de infra-estrutura de toda sorte, exigir cuidados especiais das periferias soa como inversão de valores. Se a normalidade reconhece o salário como algo justo mesmo quando irrisórios, automaticamente suspensões temporárias dos trabalhadores e auxílios governamentais serão tomadas como medidas legítimas de superação da crise.

Aliás, qual é mesmo o Leitmotiv dessa crise?

O dossiê em tela não deixa de ser nossa modesta resposta ao corte de bolsas de pesquisa em geral e à área de ciências humanas em particular. Se a relevância das esferas tecnológica e de inovação é inquestionável em pleno século XXI, desconsiderar o alcance das humanidades no entendimento de temas como democracia, política, cidadania, xenofobia, educação, cultura, ética, religião e memória - para mencionar apenas alguns - significa aderir a uma perspectiva técnico-pragmática de mundo cujo desdobramento tão perigoso quanto fatal é a completa eliminação do outro.

11 O reconhecimento do outro - que, evidentemente, somos todos nós - pertence a um conjunto de práticas sociais assentes exatamente na noção de público e no equilíbrio complexo entre liberdades particulares e garantias coletivas. No entanto, em um país dilacerado pelo escravismo, pela subalternidade e pelo autoritarismo, a ascensão do neoliberalismo e sua ênfase no individualismo fabricam o cenário perfeito para o asfixiamento da discussão sobre os sentidos do público, do social, do coletivo.

12 Fechado em si próprio, o individualismo é o caminho mais curto para a proliferação de dogmas de toda espécie. Em nome de interesses privados, cultiva pavor ao diálogo, ao contraditório, à argumentação. Talvez a pandemia possa deslocar temporariamente suas conviç̧ões. Eis uma das razões pelas quais a universidade pública, gratuita e de qualidade encarna uma ameaça ao status quo: ela orbita parcialmente fora do controle e da vigilância estatais. Certamente, o livre-pensamento possui um raio de ação que extrapola os limites do previsível. 


\section{NOTAS}

1. Eric Hobsbawm. Era dos Extremos. São Paulo: Companhia das Letras, 1994, p. 32.

\section{AUTORES}

GUILHERME RIBEIRO (PPGGEO/UFRRJ)

Email: geofilos@msn.com

FLORIANO JOSÉ GODINHO DE OLIVEIRA (PPFH/UERJ)

Email: fgodinhodeoliveira@gmail.com

LEANDRO DIAS DE OLIVEIRA (PPGGEO/UFRRJ)

Email: ldiasufrrj@gmail.com

REGINA TUNES (IGEOG/UERJ)

Email: tunesregina@gmail.com 